\title{
Irrigation Scheduling and Fertilization Improves Production Potential of Jatropha (Jatropha curcas L.): A Review
}

\author{
Anil Kumar ${ }^{1}$, N.S. Patil ${ }^{2}$, Rakesh Kumar ${ }^{3 *}$ and D. Mandal ${ }^{4}$ \\ ${ }^{1}$ Department of Agroforestry, Zonal Research Station Chianki, Palamau, Birsa Agricultural \\ University, Kanke-834 006, India \\ ${ }^{2}$ Department of Forestry, Navsari Agricultural University, Navsari, Gujarat-396 450, India \\ ${ }^{3}$ Division of Crop Research, ICAR RC for Eastern Region Patna-800 014, India \\ ${ }^{4}$ KVK, Bikramganj, BAU Sabour, Bihar-813 210, India \\ *Corresponding author
}

\section{A B S T R A C T}

\begin{tabular}{|c|}
\hline Keywords \\
\hline $\begin{array}{l}\text { Jatropha curcas, } \\
\text { Jatropha, } \\
\text { Irrigation } \\
\text { Scheduling and } \\
\text { Fertilization. }\end{array}$ \\
\hline Article Info \\
\hline $\begin{array}{l}\text { Accepted: } \\
\text { 17 April } 2017 \\
\text { Available Online: } \\
10 \text { May } 2017\end{array}$ \\
\hline
\end{tabular}

Potential of Jatropha curcas L. for producing energy from marginal land without inputs has recently drawn the attention, resulting in the planning of large commercial plantations in India and other countries. Major challenge for the extended use of J. curcas seems to be the lack of information on agro-technology and specially water and nutrient management on its potential yield under sub-optimal and marginal conditions. Therefore, it is very difficult to estimate yields from future plantations under sub-optimal growth conditions, situations where $J$. curcas is supposed to grow. There is a lack of information on basic agronomic properties of Jatropha cultivation on marginal lands in the semi-arid. Evaluation of agronomic performance of identified elite strains of $J$. curcas in marginal lands would be of paramount importance for addressing the gap areas in their agronomic properties and subsequently for harnessing their optimum economic potentials. The impacts of irrigation and nutrients on seed and oil yield of $J$. curcas in semi-arid conditions of northwest India are discussed here under this review paper.

\section{Introduction}

Energy is a vital commodity as it is commonly recognized that access to energy is closely linked with economic development (WHO, 2006). India is targeting economic growth rate of $8-9 \%$ in coming years (Kumar et al., 2016 a). It is likely to have a significant consumption of energy resources in future for meeting targeted growth rate and fulfilling energy needs of its increasing population. It lacks sufficient domestic energy resources to meet its growing energy requirements. In India, it has been projected that there is need to increase primary energy supply by at least
3-4 times by 2030 in order to maintain $8 \%$ growth rate (Kumar, 2014). Maximum contribution of renewable energy in an optimistic scenario will be $\sim 5-6 \%$ by 2030 with an import dependence on crude oil is expected to be in the range of $90 \%$ in next decade making energy security a concern (Anonymous, 2006). After coal, crude oil is the largest consumed fossil fuel in India. The known crude oil reserves are estimated to be depleted in less than 50 years at the present rate of consumption. Many countries lacking crude oil resources are facing foreign 
exchange crisis and high inflation rate mainly due to import of crude oil (Demirbas, 2005). It has been advocated to have large scale usage of renewable energy to meet the energy challenges in India. India's energy supply system has failed to meet the growing needs of rural populations and at the same time contributing significantly to environmental degradation (Kumar, 2015). It is believed that dependence on imported crude oil, environmental issues and employment in rural areas are reasons for replacement of fossil fuels by bio-fuel (Kumar et al., 2016b). Biofuels can be viable substitutes in transport for petroleum products, which account for sizable fraction of India's imports (Kumar et al., 2016c). Researchers have put forward the need for wide spread usage of renewable energy to meet the energy demand in India with the concern on competing use of land and water resources by bio-fuels, which could have an adverse impact on food security (Rajagopal et al., 2007). Self-sustainable energy sources are likely to hold the key to economic development of India in future. India should not look towards a certain group of countries to meet its ever growing needs but it is mandatory to seriously implement bio-energy development programs as a part of environmental sustainability in the form of clean development mechanism (CDM) (Kumar et al., 2010). The CDM, established by the Kyoto Protocol, promotes industrialized nations to provide resources to developing countries in order to support their sustainable development, while at the same time reducing the global green house gases (GHG) emissions since it is becoming practically impossible to reduce the emissions in their own countries (Kumar et al., 2016d). The much required green energy revolution would provide India an opportunity to change its standing from a fuel-importing nation to one that generates clean and affordable energy. Among various alternatives to the diesel, Planning Commission of India has identified Jatropha, a non-edible oil bearing tree capable of producing oil that is easily convertible in to biodiesel with properties almost similar to diesel (Anonymous, 2003). The green energy policy vis-à-vis blending requirements of diesel adopted by many countries have further increased the attention for producing more plant-based feedstock for biodiesel. European Union and India have set targets of 10 and $20 \%$ replacement of transport fossil fuel with biodiesel by 2020 (Biswas et al., 2010). Several countries have set high hopes on Jatropha to meet national blending targets. India intends to use of jatropha to reach $\sim 20 \%$ biodiesel blend with fossil diesel by 2017 (Agoramoorthy et al., 2009).

One of the main crops currently being promoted for biodiesel production in several countries, globally, is Jatropha curcas (L.). There have been substantial political and social pressures to promote the growing of such crops in many countries of the world, as a means of economic empowerment, social uplifting and poverty alleviation within marginalized communities. Jatropha is a valuable multi-purpose crop to alleviate soil degradation, desertification and deforestation, which can be used for bio-energy to replace petro-diesel, for soap production and climatic protection, and hence deserves specific attention. Jatropha can help increase rural income self-sustainability and alleviate poverty in women, elderly, children, men, tribal communities and small farmers. It can help as well to increase income from plantations and agro industries (http://www.Jatrophabiodiesel.org/aboutJatro phaPlant.php; 2007). Jatropha oil cake is rich in NPK and can be used as organic manure (Riyadh, 2002). The Jatropha oil can be used for soap and cosmetics production in rural areas and all parts of plant have traditional medicinal uses (both human and veterinary purposes) that are being scientifically 
investigated. The oil is a strong purgative, widely used as an antiseptic for cough, skin diseases, and a pain reliever from rheumatism. Jatropha latex can heal wounds and also has antimicrobial properties. Jatropha oil is an important product from the plant for meeting the cooking and lighting needs of the rural population, boiler fuel for industrial purposes or as a viable substitute for diesel. Jatropha is easy to establish, grows relatively quickly and is hardy. Being drought tolerant, it can be used to reclaim eroded areas, grown as a boundary fence or live hedge in the arid and semi-arid areas (Kobilke, 1989). While Jatropha grows well in low rainfall conditions (requiring only $\sim 200 \mathrm{~mm}$ of rain to revive) and it can also respond to higher rainfall $(1200 \mathrm{~mm})$ particularly in hot climatic conditions. Jatropha is found in the tropics and subtropics and likes heat, although it does well even in lower temperatures and withstand a light frost. Jatropha water requirement is extremely low and can stand long periods of drought by shielding most of its leaves to reduce transpiration loss (Riyadh, 2002).The genus Jatropha belongs to the tribe Joannesieae of Crotonoideae in the Euphorbiaceae family and contains $\sim 170$ known species distributed in the tropical and subtropical Africa and America. Most of the Jatropha species are native to new world and no complete review of the 66 old worlds Jatropha exists (Heller, 1996). The botanical name of Jatropha curcas L. is derived from the Greek words "Jatros" means 'Doctor' and "trophe" meaning 'Nutrition' because of medicinal properties. It is a small evergreen, nearly glabrous tree or soft wood shrub, 3 to 4 $\mathrm{m}$ high, with long petiole entire 3-5 lobed or angled, orbicular, glabrous or pubescent cymes at the end of the branches, flowers in April-may. Inflorescence is formed terminally individually, with female flower usually larger. In condition where continuous growth occurs, an unbalance of pistillate or staminate flower production results in higher number of flower. The male and female flowers exist in a ratio of 29:1. The male and female flowers are difficult to distinguish, except when they are open. Jatropha plants may produce several crops during the year if soil moisture is good and temperature is sufficiently high. Each inflorescence yields a bunch of 5-10 or more ovoid fruits. Three bi-valved cocci are formed after seed mature and mostly three seeds, quite often only $2-4$. Seeds mature when the colour of the fruits changes from green to yellow after two to four months from fertilization. The blackish thin shelled seeds are oblong resemble small castor seeds. The size of seed is $\sim 18 \mathrm{~mm}$ in length and $10 \mathrm{~mm}$ width. Seed contain $~ 30-35 \%$ non-edible oil, the kernel of these seeds contains $\sim 45-50 \%$ oil. Traditionally the kernel is used to make torches for lighting or start of a fire. Jatropha oil has high value of density 0.919 , flash point $110^{\circ} \mathrm{c}$, lubricity 50.7 and at par calorific value $9470 \mathrm{~K}$ cals $/ \mathrm{kg}$ comparable to diesel, hence, it can be readily mixed with high speed diesel and can be blended ranging from $5-20 \%$. It is also environmentally safe as it contains $0.13 \%$ sulphur (Chivandi et al., 2004). It has high saponin value 195 ( $\mu \mathrm{g} / \mathrm{litre})$.

\section{Effect of irrigation and fertilization}

Crop production is a complex process and controlled by number of factors. Jatropha productivity can be boosted through rational use of irrigation. The amount of stored soil moisture for cultivation of Jatropha, though a drought tolerant crop, may not be adequate for higher yield under varied soil and agroclimatic conditions. It responds well to irrigation. About 57\% increase in seed yield of castor due to timely and adequate irrigation was reported by Wali et al., (1991). Amongst various factors responsible for low yield, lack of irrigation facility and knowledge on water requirements and management practices, poor supply of nutrients by avoiding use of 
fertilizers seems to be the chief causes. Among this moisture shortage at critical growth stage reduced the yield drastically (Michael, 1978). Proper moisture balance needs to be maintained for satisfactory growth and yield of the Jatropha. The knowledge about the water used at critical periods by crop during its growth is essential for its judicious application. This essentially is more important when water supply is either limited or very costly. The importance of critical growth stages of crop growth for irrigation and needs of Jatropha. Jatropha crop with its profuse branching after pruning and extensive root system has higher production potential and is highly responsive to supplemental nutrients and irrigation. Use of fertilizer appears to be answer to solve lower production of Jatropha. Fertilizer increases efficiency of irrigation water and in fact irrigation without fertilizer is like a resource wasted. Fertilizer use also improves turnover of labour charges i.e. cost of cultivation.

Of all the major nutrients provided to agricultural crops, nitrogen is generally considered the most important for plant growth. It is a constituent of many components in plants, including all proteins, which build cell material and plant tissue and production of chlorophyll, making photosynthesis possible. Many enzymes need nitrogen for assimilation of nutrients and also the nucleic acids involved in reproduction of the genetic code, DNA and RNA, is dependent of nitrogen (Taiz and Zeiger, 2004). Nitrogen is the principal growth stimulating element and is important for maintaining vigour and health of tree. It greatly influences leaf growth, leaf area duration and photosynthetic rate per unit leaf area to control production of carbohydrate and other photosynthetic products and influences numbers and sizes of vegetative and storage organs (Engels and Marscher, 1995). Beside from nitrogen, phosphorus is the nutrient that will also limit plant productivity if it is deficient. Phosphorus is beneficial for healthy plant growth, especially in reproductive structures. A large quantity of phosphorus is stored in the seeds or fruit of plants and is considered essential for seed formation (Havlin et al., 1999). Phosphorus plays a vital role in nearly every metabolic reaction in all living things. It is a component of numerous cell structures such as phospholipids, nucleotides, coenzymes, sugar phosphates, and nucleic acids. An important function of potassium is to keep plant cell turgid controlling osmotic processes in cell sap. This abundant, nontoxic, mono-valent cation is important in maintaining ionic balance or electrical neutrality in plants. Its role in ionic balance may be one reason that $\mathrm{K}$ is found in higher concentration in both xylem and phloem saps.

Potassium regulates normal functioning of metabolic processes within cells. Potassium acts as an activator of numerous enzymes. Potassium is essential for protein synthesis (Peoples and Koch, 1979). Morphogenic effects of $\mathrm{K}$ include increased number of storage cells to effect sink capacity of grains (Shuman, 1994). It is essential to maintain the supply of moisture, NPKS at optimum levels in the soils to exploit full potential of jatropha. To find out the effect of irrigation scheduling and fertilization and levels on production potential of jatropha was reviewed with following objectives: to find out the effect of fertilizer and irrigation levels on growth, yield and quality of jatropha and to find out optimum schedule of irrigation and dose of fertilizer for jatropha. Also to study the effect of fertilizer and irrigation levels on nutrient content of jatropha.

Effect of irrigation on growth and yield attributes, yield and quality of jatropha

Abdrabbo et al., (2008) carried out a field experiment in Egypt where jatropha was transplanted and treated after the second year 
of the transplanting by different amounts of water stress, viz. 125, 100, 75 and $50 \%$ of potential evapo-transpiration $\left(\mathrm{ET}_{\mathrm{P}}\right)$. Results revealed that the average water consumption rate of Jatropha is 6 liter per week throughout the growing season, which means that jatropha can survive and produce full yield with high quality seeds with minimum water requirements compared to other crops. The yield of extracted oil was 85.5, 175.2, 90.5 and $66.5 \mathrm{~kg} / \mathrm{ha}$ at $125,100,75$ and $50 \% \mathrm{ET}_{\mathrm{P}}$, respectively. The lowest value of total lipid (oil) (25 and $24.5 \%$ of Jatropha seeds) was recorded with jatropha trees irrigated by 125 and $50 \%$ of ETp, respectively. On the other hand, the treatment that was irrigated by $100 \%$ of ETp (control) recorded the highest value of total oil in the seeds $(29.9 \%)$. Under greenhouse condition, Achten et al., (2010) applied three levels of treatments of drought stress and monitored growth variables and biomass production of Jatropha curcas seedlings propagated from three seed accessions. Well-watered $J$. curcas seedlings grew $0.81+$ or- $0.15 \mathrm{~cm} \mathrm{day}^{-1}$ in length and produced 1.49 +or- $0.31 \mathrm{~g}$ dry biomass day ${ }^{-1}$. Under medium stress $(40 \%$ plant available water) the plants maintained a similar stem shape, although they grew at lower rate (stem length: $0.28+$ or $-0.11 \mathrm{~cm} \mathrm{day}^{-1}$; dry biomass production: $0.64+$ or- $\left.0.18 \mathrm{~g} \mathrm{day}^{-1}\right)$. Seedlings under extreme drought stress (no irrigation) stopped growing, started shedding leaves and showed shrinking stem diameter from the 12th day after the start of the drought treatment. The root/shoot ratio of the wet treatment was 0.27 , which is low compared to other tropical trees.

An experiment was conducted at Sardar Krusinagar (Gujarat) in sandy loam soil for irrigation study on castor hybrids (GAUCH-1 and $\mathrm{GCH}-4)$ with two depths of irrigation water (50 and $75 \mathrm{~mm}$ ) and four IW/CPE ratios $(0.4,0.6,0.8$ and 1). The irrigation water depth of $75 \mathrm{~mm}$ gave significantly more yield over $50 \mathrm{~mm}$. Application of irrigation water at IW/CPE ratio of 1.0 gave significant enhancement in castor seed yield as compared to less frequent irrigation. As the frequency of irrigation decreased, there was concomitant reduction in seed yield of castor. The increased yield was due to more number of effective spikes per plant (Anonymous, 1990a). Similarly, a study was conducted in Gujrat to evaluate the effect of drip irrigation on castor hybrids GCH-4 with treatments viz. $0.4,0.6$, and 0.8. IW/CPE ratios and flood irrigation. Results revealed that after application of irrigation at $0.8 \mathrm{IW} / \mathrm{CPE}$ ratio offered substantially more seed yield (3446 $\mathrm{kg} / \mathrm{ha}$ ) than irrigation application by 0.4 IW/CPE ratio and flood irrigation. Higher seed yield was due to greater spike length of main spike, no. of capsule on main spike and effective spike/plant (Anonymous, 1990 b). Azza et al., (2010) studied the influence of some soil media (sand, clay and sand + clay) under different water regimes (500, 1000, 1500 and $2000 \mathrm{~cm}^{3} /$ pot) on growth and chemical constituents of Jatropha curcas L. Results showed that increasing water supply gradually increased significantly plant height, stem diameter, number of leaves/plant, leaf area, fresh and dry weight of leaves and stem. Same behavior was noticed concerning chlorophyll a, b, a $+\mathrm{b}$, carotenoids content as well as N, P and $\mathrm{K}$ uptake in shoots. On the contrary, root length, fresh and dry weight of roots as well as NPK and proline content increased as water level decreased. From the three years experimentation on castor, determination of irrigation scheduling, Patel et al., (1999) reported that the highest yield (2930 kg/ha) was obtained at 0.5IW/CPE ratio. They further stated that castor $\mathrm{GCH}-4$ should be irrigated with four irrigations each of $80 \mathrm{~mm}$ depth.

Nagabhushnam and Raghavaiah (2005) at Hyderabad, with castor hybrid DCH-177 (Deepak) grew under four irrigation regimes 
(irrigation at 15-day intervals and irrigation at IW/CPE of 0.4, 0.6 and 0.8 ). It was noted that scheduling irrigation at IW/CPE of 0.8 (wet regime) resulted in significantly higher castor bean growth and yield. Oil content was not significantly influenced by irrigation regimes. Raj et al., (2010) conducted a field experiment at Sardarkrushinagar to find out suitable method of irrigation and highyielding hybrids of castor.

The highest growth parameters viz. plant height at 90 and 120 days after sowing as well as at maturity and yield attributes, like length of spike, capsule/spike, effective spikes/plant, seed yield/primary spike and seed yield/plant were recorded in the treatment receiving 60 $\mathrm{mm}$ irrigation in all the furrows at $0.8 \mathrm{IW}$ : $\mathrm{CPE}$ ratio, followed by alternate furrows with $45 \mathrm{~mm}$ irrigation. Highest seed and stalk yield with maximum net realization of Rs. 58187/ha was recorded with irrigation in all the furrows, followed by alternate to alternate furrow with $45 \mathrm{~mm}$ irrigation with net realization of Rs.56258/ha but alternate to alternate furrow with $45 \mathrm{~mm}$ irrigation recorded the maximum $\mathrm{B}: \mathrm{C}$ ratio of 3.01 . The highest growth parameters and yield attributes as well as seed and stalk yield was recorded in castor hybrid ' $\mathrm{GCH} 5$ ' with maximum net realization of Rs. 53287/ha with benefit: cost ratio of 2.92 was also obtained in ' $\mathrm{GCH} 5$ '. Rodrigues et al., (2009) conducted an experiment to evaluated effect of irrigation with domestic wastewater on the growth and seed production of castor bean. Castor bean irrigated with $0.60 \mathrm{ETc}$ in relation to 1.05 ETc had decreased plant height, stem diameter, leaf number, leaf area and seed production by $23.5,16.1,26.2,44.1$ and $50.6 \%$, respectively. BRS Paraguacu had plant height significantly higher than that of BRS Nordestina, while BRS Nordestina had larger leaf area at 48 and 90 DAS. However, their seed production had similar values. Samutthong et al., (2007) studied the effects of amount and rate of watering on growth and yield of Cassava cultivar in Thailand. Treatments were control (cassava under rain fed condition without additional irrigation); additional watering of $30 \mathrm{~mm}$ at one time mo ${ }^{1}$, split twice $\mathrm{mo}^{-1}(15 / 15 \mathrm{~mm})$ and split 3 times $\mathrm{mo}^{-1} \quad(10 / 10 / 10 \mathrm{~mm})$; additional watering of $45 \mathrm{~mm}$ at one time $\mathrm{mo}^{-1}$, split twice $\mathrm{mo}^{-1}(22.25 / 22.25 \mathrm{~mm})$ and split thrice $\mathrm{mo}^{-1}(15 / 15 / 15 \mathrm{~mm})$; additional watering of $60 \mathrm{~mm}$ split twice $\mathrm{mo}^{-1}(30 / 30 \mathrm{~mm})$ and split 3 times $\mathrm{mo}^{-1}(20 / 20 / 20 \mathrm{~mm})$.

The results indicated that cassava in split 3 times $\mathrm{mo}^{-1}(20 / 20 / 20 \mathrm{~mm})$ produced significantly greater yields. Sharma et al., (2008) studied the effect of irrigation on growth and yield on two and half years old jatropha at CSSRI Karnal, Haryana. They applied four irrigation frequencies $(0,2,4,6)$ and observed that 4 irrigation was effective in giving maximum plant height $(311 \mathrm{~cm})$, canopy spread $(234 \mathrm{~cm})$, no. of fruiting branches (16)/plant, no. of fruit (221)/ plant and fruits weight $(670 \mathrm{~g}) /$ plant. Whereas, maximum no. of branches/plant (31) and branch diameter $(5.53 \mathrm{~cm})$ was observed at 6 irrigation.

Also studied at Bharuch, Gujarat and reported the response of Jatropha to salinity and saline water irrigation tolerance to water stagnation/water logging and observed that irrigating Jatropha plant at 10 days interval altogether 90 liter of water in 6 irrigation was found giving significantly maximum plant height $(1.36 \mathrm{~m})$, seed yield $(268 \mathrm{~g} / \mathrm{plant})$, seed yield $(2977 \mathrm{~kg} / \mathrm{ha})$ Seed oil content (35.2) Seed oil yield $(1047.9 \mathrm{~kg} / \mathrm{ha})$

Effect of fertilizer on growth and yield attributes, yield and quality of Jatropha

Yadhav et al., (1995) studied the effect of different plant densities and fertilizer levels on growth of jatropha. Results revealed that with the increase in levels of fertilizer, plant 
height, girth, leaves/plant, petiole length, leaf area/plant, LAI and AGR of height and girth were progressively increased. Application of $3.6 \mathrm{~g}$ each of $\mathrm{N}, \mathrm{P}_{2} \mathrm{O}_{5}$ andK $\mathrm{K}_{2} \mathrm{O} /$ plant at wider spacing produced maximum height $(67.2 \mathrm{~cm})$, girth $(7.5 \mathrm{~cm})$ and AGR of $(7.3 \mathrm{~cm} /$ month). Vergine Tenshia (2006) a study conducted on the effect of fertilizers and manures on growth, yield, nutrient uptake, soil fertility and fuel quality of jatropha in vertisols of Coimbatore district revealed that the application of $30: 100: 50 \mathrm{~kg} \mathrm{~N}, \mathrm{P}_{2} \mathrm{O}_{5}$ and $\mathrm{K}_{2} \mathrm{O}$ $\mathrm{ha}^{-1}$ in combination with FYM, biofertilizer and micronutrient mixture excelled in increasing growth, yield and oil content, besides maintaining the soil fertility. Suriharn et al., (2011) studied the effects of pruning level and fertilizer on growth and yield of three-year old physic nut. Application of fertilizer did increase branch number and branch length especially at the rate of 312.5 $\mathrm{kg} \mathrm{ha}{ }^{-1}$. They recommended applying fertilizer to the three-year old physic nut under rain fed conditions at the rate not exceeding $312.5 \mathrm{~kg} \mathrm{ha}^{-1}$. Application of higher rates depressed yield. Swaminathan (2006) at AICRP, Coimbatore revealed application of $50: 100: 50 \mathrm{~kg} \mathrm{~N}, \mathrm{P}_{2} \mathrm{O}_{5}$ and $\mathrm{K}_{2} \mathrm{O}$ per hectare $\left(20: 40: 20 \mathrm{~g} \mathrm{~N}, \mathrm{P}_{2} \mathrm{O}_{5}\right.$ and $\mathrm{K}_{2} \mathrm{O}$ per plant)in Coimbatore with FYM, bio-fertilizer and micronutrient mixture excelled in increasing growth, yield and oil content of Jatropha, besides maintaining the soil fertility. Singh et al., (2003) conducted an experiment to see the effect of fertilizer application on growth and biomass production of mulberry. They applied different combinations of NPK fertilizers with control and concluded that comparative study of different treatments of fertilizer doses on performance with respect to branches, shoot length and leaf yield shows that application of $250 \mathrm{~kg} / \mathrm{ha} / \mathrm{yr} \mathrm{N}, 120$ $\mathrm{kg} / \mathrm{ha} / \mathrm{yr} \mathrm{P}$ and $100 \mathrm{~kg} / \mathrm{ha} / \mathrm{yr} \mathrm{K}$ during spring season and $200 \mathrm{~kg} / \mathrm{ha} / \mathrm{yr} \mathrm{N}, 120 \mathrm{~kg} / \mathrm{ha} / \mathrm{yr} \mathrm{P}$ and $120 \mathrm{~kg} / \mathrm{ha} / \mathrm{yr} \mathrm{K}$ during autumn season is economic. Singh et al., (2006) carried out a field experiment during rainy and winter at ARS, Mandor (Rajasthan) Plant height up to main raceme of castor was improved significantly with application of $75 \% \mathrm{RDF}+$ $25 \% \mathrm{~N}$ through FYM + Azospirillum + PSB culture compared with $100 \%$ RDF. The same treatment also gave highest seed and oil yield of 2816 and $1366 \mathrm{~kg} / \mathrm{ha}$, respectively. This treatment improved the seed yield by 18.7 and $26.2 \%$ over 75 and $50 \%$ RDF, respectively. Shirisha et al., (2010) conducted a field experiment to study the effect of INM on growth and yield of castor. The maximum plant height and dry matter was observed with $75 \%$ recommended dose of nitrogen $(\mathrm{RDN})+$ $25 \% \mathrm{~N}$ through poultry manure also resulted in longer primary and secondary spikes; more number of capsules/spike. Integrated use of inorganic fertilizer with organic manures recorded seed yield similar to that of $100 \%$ RDN. Though, oil yield was highest with application of $75 \% \mathrm{RDN}+25 \% \mathrm{~N}$ through poultry manure.

Singh (2009) studied an experiment to see the effect of three major essential nutrients $(\mathrm{N}, \mathrm{P}$ and $\mathrm{K}$ ) with and without organic manures on the growth of jatropha in nursery. Various combinations of NPK with and without FYM were tested. Out of nine treatments combination i.e. $75-50-12.5 \mathrm{kgN}-\mathrm{P}_{2} \mathrm{O}_{5}-$ $\mathrm{K}_{2} \mathrm{O}+5$ tonnes of $\left.\mathrm{FYM} / \mathrm{ha}\right)$ produced the maximum height $(1.61 \mathrm{~m})$ and maximum diameter $(3.39 \mathrm{~cm})$ of Jatropha curcas. Severino et al., (2006) carried out a trial in Brazil to determine the effects of application of mineral fertilizer containing macronutrients and micronutrients on growth, sexual expression and yield of castor bean (Ricinus communis) cV. BRS Nordestina. The nutrition $\mathrm{N}, \mathrm{P}$ and $\mathrm{K}$ were applied at 50, 60 and 40 $\mathrm{kg} /$ ha respectively. The characteristics related to plant growth were only slightly affected by the treatments. Seed oil content increased in response to $\mathrm{P}$ application. Higher $\mathrm{N}$ and $\mathrm{K}$ rates resulted in an alteration in the sexual 
expression of the crop in favor of higher yield. Crop yield increased from 1072 to 2298 $\mathrm{kg} / \mathrm{ha}$ due to $\mathrm{N}$ fertilizer. Rajannan (2006) revealed that jatropha growth viz., plant height, collar diameter number of branches and number of leaves were higher, when excess nutrient uptake plots i.e.150\% RDF (20:100:120g urea: SSP: MOP), respectively. Reddy and Matcha (2010) studied pot-culture experiment and determined $\mathrm{N}$ deficiency effects on castor bean plant growth and physiology. After 34 DAS, the treatments imposed were full-strength Hoagland's nutrient solution (control, $100 \mathrm{~N}$ ), reduced $\mathrm{N}$ to $20 \%$ of control $(20 \mathrm{~N})$ and no $\mathrm{N}(0 \mathrm{~N})$ until final harvest, 66 DAS. Maximum growth and developmental rates were achieved at $7.0 \mathrm{~g} \mathrm{~N}$ $\mathrm{kg}^{-1}$, much higher than many other crops grown under similar nutrient conditions. Even though all growth rates declined with lower leaf $\mathrm{N}$, leaf area expansion was more sensitive to leaf $\mathrm{N}$ followed by rates of stem elongation, node addition and photosynthesis. Critical leaf $\mathrm{N}$ levels (90\% of maximum) varied for various processes; $55.3 \mathrm{~g} \mathrm{~N} \mathrm{~kg}^{-1}$ for stem elongation, $63 \mathrm{~g} \mathrm{~N} \mathrm{~kg}^{-1}$ for node

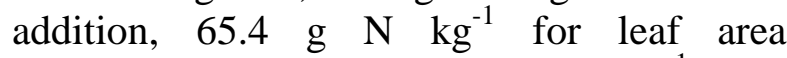
expansion, and $60.3 \mathrm{~g} \quad \mathrm{~N} \quad \mathrm{~kg}^{-1}$ for photosynthesis. Among plant components, leaf dry weight had the greatest decrease while root/shoot ratio increased under $\mathrm{N}$ deficiency. In a rabi castor, in determination of irrigation scheduling and INM, Reddy et $a l .$, (2006) reported that total seed yield was recorded significantly higher with 0.6 IW/CPE ratio and INM practices with $75 \%$ $\mathrm{RDF}+25 \% \mathrm{~N}$ through FYM + Azospirillum. Interaction between IW/CPE ratio and INM practices on total seed yield revealed that maximum seed yield was obtained with 0.6 IW/CPE at $75 \%$ RDF $+25 \% \quad \mathrm{~N}$ through FYM+ Azospirillum. Patel et al., (1991) reported that castor seed yield was significantly higher when $75 \mathrm{~kg}$ N/ha was applied to plants in three split doses in hybrid irrigated castor (GAU-CH-1). Patel et al.,
(2005) concluded that plant height and no. of branches/plant were significantly higher at $80 \mathrm{~kg} \mathrm{~N} / \mathrm{ha}$ in (rabi) castor. Patil et al., (2006) conducted two experiments to standardize nutritional levels on growth and yield of jatropha under rain fed conditions at Dharwad and Prabhunagar. Results revealed collar diameter, no. of branches and seed yield of jatropha were significantly higher with sulphur applied @ 60kg/ha compared to 20kg/ha. Whereas, at Prabhunagar, application of 80:80:80 N: P: K g/plant had recorded significantly higher no. of branches, collar diameter and seed yield compared to 40:40:40 N: P: K g/plant. In a series of experiment, Raghavaiah (1999) studied the influence of fertilizer on castor hybrids and revealed that the hybrid DCH 177 out yielded the other test hybrids DCH 178, DCH 30, $\mathrm{GCH}$ 4. Also the genotype interacted favorably with fertilizer, where DCH 177 when fertilized with $75 \% \mathrm{RDF}+\mathrm{FYM} 5 \mathrm{t} / \mathrm{ha}$ offered distinct improvement in seed yield over rest of the treatments. However scanty rainfall as in response to applied fertilizer was not discernible although application of organic manure showed beneficial effect. Hybrids differed in oil content, while fertilizer application had a desirable effect on oil content.

Kalannavar and Angadi (2009) studied response of Jatropha curcas to NPK levels on growth, yield and quality of Jatropha. There were twenty eight treatment combinations consisting of three levels each of nitrogen (50, 100 and $150 \mathrm{~kg} \mathrm{~N} \mathrm{ha}^{-1}$ ), phosphorus (100, 150 and $200 \mathrm{~kg} \mathrm{P}_{2} \mathrm{O}_{5} \mathrm{ha}^{-1}$ ) and potassium (100, 150 and $200 \mathrm{~kg} \mathrm{~K}_{2} \mathrm{O} \mathrm{ha}^{-1}$ ). Significantly higher seed yield, oil yield and biodiesel yield of Jatropha was recorded with $100 \mathrm{~kg} \mathrm{~N}^{-1}$ over 50 and $150 \mathrm{~kg} \mathrm{~N} \mathrm{ha-1}$. Among phosphorus levels, significantly higher seed yield, oil yield and biodiesel yield was recorded with $100 \mathrm{~kg} \mathrm{P}_{2} \mathrm{O}_{5} \mathrm{ha}^{-1}$. Application of $150 \mathrm{~kg} \mathrm{~K} \mathrm{~K}_{2} \mathrm{O} \mathrm{ha}^{-1}$ recorded significantly 
higher seed yield, oil yield and biodiesel yield. Mahapatra and Panda (2011) studied effect of NPK fertilizers on the yield attributing characters of Jatropha. Five year old plantation was treated with two levels of $\mathrm{N}$ (50 and 60g/plant), P (80 and 100g/plant) and $\mathrm{K}$ (60 and 75g/plant) either alone or in combination and results revealed that significant difference in growth as well as yield characters due to application of inorganic fertilizers. While maximum seed yield of $427.21 \mathrm{~kg} / \mathrm{ha}$ was recorded in N60 treatment, seed oil content varied significantly from 32 to $35 \%$ under various regimes of NPK application. Treatment with $\mathrm{N}_{60} \mathrm{P}_{100} \mathrm{~K}_{60}$ and $\mathrm{N}_{60}$ resulted in consistent higher yield of seed oil. Mani et al., (2005) reported that the application of NPK fertilizer @ $50: 75: 75 \mathrm{~kg} / \mathrm{ha}$ along with FYM @ 12.5t/ha and azophos @ 25kg/ha significantly enhanced number of branches, collar diameter, leaf area, plant height and total dry matter and yield attributes such as pod yield, seed yield and 100 seed weight, available NPK contents were significantly higher due to combined application of FYM, azophos and NPK fertilizer@ 50:75:75kg/ha. Murthy and Padmavathi (2009) studied the influence of potash treatments comprised of 7 levels viz., 0, 20, 40, 60, 80, 100, 120kg K2O/ha. Results showed that castor seed yield responded positively to the potassium $(\mathrm{K})$ doses and optimum doses of $\mathrm{K}$ derived with linear responses plateau equation were $87\left(r^{2}=0.98\right)$ for DCS-9 variety and $72\left(\mathrm{r}^{2}=0.79\right) \mathrm{kg}$ $\mathrm{K} 2 \mathrm{O} / \mathrm{ha}$ for DCH-32 hybrid. Further, the fertilization has influenced the $\mathrm{Mg}, \mathrm{Fe}, \mathrm{Mn}$ and $\mathrm{Cu}$ uptake in DCS-9 seed while $\mathrm{Mg}$ and $\mathrm{Cu}$ uptake in DCH-32 seed. Gajare and Patil (2008) studied the influence of levels of pruning and fertilizers on growth and yield of Jatropha curcas. The result revealed that application of fertilizers (80:80:80 g.N: $\mathrm{P}_{2} \mathrm{O}_{5}: \mathrm{K}_{2} \mathrm{O}$ per plant) had recorded significant higher in number of branches, collar diameter, and seed yield (15.77,
$18.71 \mathrm{~cm}$ and $727.96 \mathrm{~g}$ per plant respectively) were compared to other levels. Arisoa et al., (2010) studied the influence of irrigation on 3 years old winter pruned jatropha plants at South-West Madagascar. Findings indicated that neither crop growth rate nor LAI were increased by irrigation but effects are expected during later sampling dates. Dry mass of newly formed twigs and leaves were correlated with pre-existing branch dry matter and volume indicating the significance of reserves from pre-season growth phases for actual growth potential. Based on additional information from nutrient concentration it is concluded that Jatropha must be considered as a high-input crop if profitable oil production is the target. Alam and Ali (2008) studied the effect of organic and inorganic sources of nutrients with irrigation scheduling on growth performance of Jatropha curcas cuttings. They applied 9 treatments comprised of source of nutrients in a different combination and irrigation was applied at 3day-interval; weekly interval; and fortnightly interval. The mean value of the parameter revealed that maximum plant height, branch length, collar diameter and volume index were obtained in case of $200 \mathrm{~g} \mathrm{SSP}+100 \mathrm{~g}$ MOP. Almeida Junior et al., (2009) evaluated the effect different phosphorus doses on development of Castor. They applied different phosphorus doses as treatments consisted of $(0,3,6,9,13$ and $15 \mathrm{~g} /$ plant $)$. They evaluated the no. of leaves, leaf area, and height and stem diameter. Phosphate showed positive response in all characteristics evaluated. The best results were found with a dose of 9 g/plant P.

\section{Interaction effect irrigation $\times$ fertilization on growth, yield attributes and quality of Jatropha}

Sarhan et al., (2010) conducted a trial in Egypt on Jatropha. The treatments applied were of irrigation at three different viz. 7, 14, 
and 21 days interval using sewage water and fertilizer with calcium superphosphate $(15 \%$ $\left.\mathrm{P}_{2} \mathrm{O}_{5}\right)$, potassium sulphate $\left(50 \% \mathrm{~K}_{2} \mathrm{O}\right)$ every two months @ 0:0, 50:25, 75:37.5 and $100: 50 \mathrm{~g} /$ plant. Irrigation at 7 days intervals and fertilization with 100:50g/plant increased vegetative growth, fruit yield and oil percentage as compared to other treatments. Hadvani et al., (2010) carried out a field experiment to study the effect of nitrogen and potassium levels on growth, yield attributes and yield of castor GCH-4 under irrigated condition at Junagadh. The results indicated that the castor crop fertilized with $100 \mathrm{~kg} \mathrm{~N}$ $\mathrm{ha}^{-1}$ was significantly increased in plant height, number of branches per plant and yield attributes viz. length of main spike per plant, seed yield per plant and 100 seed weight over control. When the crop fertilized with75 kg N ha ${ }^{-1}$ ) significantly higher seed (2563) and stalk (3138 $\left.\mathrm{kg} \mathrm{ha}^{-1}\right)$ yield by 100 $\mathrm{kg} \mathrm{N} \mathrm{ha}{ }^{-1}$ were recorded. Fertilizing castor with $75 \mathrm{~kg} \mathrm{~K}_{2} \mathrm{O} \mathrm{ha}^{-1}$ significantly increased plant height at harvest, no. of capsules per main spikes, length of main spikes, test weight, yield/plant over control. Application of $50 \mathrm{~kg} \mathrm{~K}_{2} \mathrm{O} \mathrm{ha}^{-1}$ significantly increased seed yields $\left(2713 \mathrm{~kg} \mathrm{ha}^{-1}\right)$ at $75 \mathrm{~kg} \mathrm{~K}_{2} \mathrm{O}$ ha $^{-1}$ over control. The study indicated that the higher production from irrigated castor can be secured with $75 \mathrm{~kg} \mathrm{~N}$ and $75 \mathrm{~kg} \mathrm{~K}_{2} \mathrm{O}$ ha $^{-1}$ along with $50 \mathrm{~kg} \mathrm{P}_{2} \mathrm{O}_{5} \mathrm{ha}^{-1}$.]

In conclusion, Jatropha's ability to grow or cultivate successfully and easily on arid lands with poor quality soils and scarce water in Egypt makes it an ideal plant for successfully revegetating wastelands. Jatropha must be recognized for more than its traditional value as a hedgerow species or as a local source of medicine in many areas in the world. Undeniably there exists value in its potential for revegetating degraded lands with what is an economically and socially valuable crop. These new ideas regarding the use of Jatropha must be looked at objectively when determining priorities for increased efforts and financial inputs into Jatropha establishment. It can be concluded that Jatropha is a promising source of biofuel in diesel engines or as an extender for diesel fuel in farm machinery, electrical generators, irrigation pumps, lighting, heating and cooking fuel. Cultivating Jatropha in the Egyptian desert, rural areas and remote communities is very useful economically, socially and environmentally. The crop should be fertilized with optimum levels to realize the optimal economic yield. Therefore, standardization of agronomic properties for growing jatropha on marginal lands is highly desirable. Furthermore, testing suitability of the elite clones of jatropha in marginal lands is also important for obtaining profuse yield.

\section{Future goal}

The result of this experiment should be confirmed by repeating it at least for one or two season for consistency and applicability as recommended practices for farmers. To increase irrigation efficiency it is necessary to study the impact of drip irrigation on jatropha. More study should be conducted to know the interaction of fertilizer and irrigation in relation to cultural practices like weed management and spacing. The similar study should be conducted by taking dwarf variety of Jatropha with drip irrigation and fertilizer to have better prospect of this green gold crop.

The results obtained in the present investigation, should be taken up at different locations for its adoptability. The optimum level of nutrition and water requirement of $J$. curacs for commercial scale with economic viability cannot be defined as this will change with the age of plantation. Therefore, the fertilizer and water requirement studies need further long-term evaluation. 


\section{Acknowledgments}

The authors are thankful to the faculty members of the Department of Forestry, APSEE College Navsari, Gujrat for supporting this research. The authors are also thankful to seniors and juniors for helping in collecting the review literature. Thanks are also due to anonymous referees of the journal for their insightful comments that helped sharpen the arguments put forward in this paper.

\section{References}

Abdrabbo, A., Abou, K., and Nahed, M.M. 2008. Response of Jatropha curcas L. to water deficit, yield, water use efficiency and oilseed characteristics. Biomass and Bioenergy, 1-2 pub. online.

Achten, W.M.J., Maes, W. H., Reubens, B., Mathijs, E., Singh, V. P., Verchot, L., and Muys, B. 2010. Biomass production and allocation in Jatropha curcas L. seedlings under different levels of drought stress. Biomass and Bioenergy, 34(5): 667-676.

Agoramoorthy, G., Hsu, M.J., Chaudhary S., Shieh, P.C. 2009. Can biofuel crops alleviate tribal poverty.

Alam, I. and Ali, M.S. 2008. Effect of organic and inorganic source of nutrient with irrigation scheduling on growth performance of Jatropha curcas (L.) cuttings. Biosci., 5(1): 363-368.

Almeida Junior, A.B., de Oliveira, F. de A., de Medeiros, J.F., de Oliveira, M.K.T. and de Linhares, P.C.F. 2009.Effects of phosphorus doses in initial development of the castor bean. Caatinga, 22(1): 217-221.

Anonymous.1990a. Identification of efficient irrigation schedule for Castor hybrid GCH-4. Annual progress report, AICRP, Rajendranagar, Hyderabad. pp: 77-78.
Anonymous.1990b. Studies on drip irrigation for Castor hybrid GCH-4 Annual progress report, AICRP, Rajendranagar, Hyderabad. pp: 79-81.

Anonymous. 2006. Nutrient requirement in Jatropha Website www.Jatropha world.org.

Arisoa, R., Holger, B., and Folkard, A. 2010. Response of Leaf Area and Biomass partitioning of Physic nut to variable water Supply. Proc. on World Food System. A Contribution from Europe" Tropentag, September 14-16, Zurich(Germany).

Azza, A.M., Mazhaz, N.G., Abd, El. A., and Habba, E.El. 2010. Impact of different soil media on growth and chemical constituents of Jatropha (Jatropha curcas L.) seedlings grown under water regime. J. American Sci., 6(8): 549-556.

Biswas, P.K., Pohit, V. and Kumar, R.2010. Biodiesel from Jatropha: Can India meet the 20\% blending target? Energy Policy, 38: 1477-1484.

Chivandi, E., Mtimuni, J.P., Read, J.S. and Makuza. 2004. Effect of processing method on phorbol easter concentration, total phenolics, trypsin inhibitor activity and the proximate composition of Zimbawean Jatropha curcas: A potential live stock feed, Pak. J. Biol. Sci., 7(6): 1001-1005.

Demirbas, A. 2005. J Scientific and Industrial Res., 64: 858- 65.

DFID. 2002. http://www.dfid.gov.uk/pubs/files/energ yforthepoor.pdf.

Engels, C. and Marschner, H.1995. Plant uptake and utilization of nitrogen.pp.4181.In: PF., Bacon (ed). Nitrogen Fertilization in the Environment. New York; Marcel Dekker.

Gajare, S.R. and Patil, S.K. 2008. Influence of levels of pruning and fertilizers on growth and yield of Jatropha curcas (L.) Karnataka J. Agric. Sci., 21(4): 
637-638.

Hadvani, N.G., Jadavd, K.V., and Hadvani, G.J. 2010. Responses of Castor (Ricinus communis L.) to nitrogen and potassium levels on growth, yields attributes and yields under irrigation condition. Advances in Plant Sci., 23(1): 165-167.

Halvin, J.L., Beaton, J.D., Tisdale, S.L. and Nelson, W.L.1999. Soil fertility and fertilizer- An introductory to nutrient management $6^{\text {th }}$ Ed. Prentice Hall. New Jersey.

Heller, J. 1996. Physic nut (Jatropha curcas L.) promoting the conservation and use of underutilized and neglected crops. Institute of Plant Genetics and Crop Plant

Research, Gatersleben/International Plant Genetic Resources Institute Rome, Italy.

http://www.Jatrophabiodiesel.org/aboutJatrop haPlant.php; 2007 [accessed 18.02.2007].

Kalannavar, V.N. And Angadi, S.S. 2009. Response of Jatropha curcas to nitrogen, phosphorus and potassium levels in northern transition zone of Karnataka. Karnataka J. Agric. Sci, 22 (5): 1198-1170.

Kobilke H. 1989. Unteruschingen zur Bestand esbegrindung on porgies nub 1 Jatropha curcas. Diploma Thesis, University of Hohenheim, Stetting.

Kumar, A., Patil, N.S. and Kumar, R.2016a.Response of irrigation scheduling and fertility levels on productivity and nutrient uptake of jatropha (Jatropha curcas L.). The Bioscan, 11(4): 2411-2415.

Kumar, A., Patil, N.S. and Kumar, R. 2016b. Productivity, water use efficiency and nutrient content of Jatropha (Jatropha curcas L.) as influenced by varying irrigation scheduling and fertility levels. Int. J. Agri. Statistical Sci., 12(S 1): 261-266.

Kumar, A., Patil, N.S. and Kumar,
R.2016c.Effect of irrigation schedules and fertility levels on growth, yield and economics of Jatropha (Jatropha curcas L.) under South Gujarat condition. Environment \& Ecology 34 (4D): 2561-2565.

Kumar, A., Patil, N.S. and Kumar, R.2016d.Production potential and quality of jatropha (Jatropha curcas L.) as influenced by irrigation schedules and fertility levels. Ecol. Environ. Conservation, 22(4): 1835-1840.

Kumar, R. 2014. Biochemical characterization of Jatropha (Jatropha curcas L.) accession in Eastern Himalaya, India. The Bioscan, 9(3): 1131-1134.

Kumar, R. 2015. Morphological characterization of jatropha (Jatropha curcas L.) accession in Eastern Himalaya, India. Ecology, Environ. Conservation, 21(4): 2021-2025.

Kumar, S. Chaube, A. and Jain, S.K. 2010. J. Env. Res. Develop., 4(3): 877-884.

Mahapatra, S. and Panda, P.K. 2011. Effect of fertilizer application on growth and yield of Jatropha curcas L. in an aeric tropa quept of eastern India. Not. Sci. Biol., 3(1): 95-100.

Mani, A.K., R. Shanthi, K.M. Sellamuthu, V. Karikalan and Manivaskan, S.2005. Integrated Nutrient Management of Jatropha. ICAR. Winter school on strategies for production, processing and development of biofuels.

Michael, A.M. 1978. Crop response to water at different stages of growth. Irrigation theory and practice, Vikas publishing house Pvt. Ltd. 560.

Nagabhushanam, U. Raghavaiah, C. V. 2005.Seeding date and irrigation effects on the productivity and oil quality of post-monsoon grown castor, Ricinus communis L. in Alfisols. J. Oilseeds Res, 22(1): 206-208.

Patel, C.K., Rana, C.H., Kaswala, R.R., Patel, 
M.L., Maliwal, G.L., and Raman, S.1999.Water management technology developed for Phase-1 of Narmada command (Black soil).In. Water management research in Gujarat (ed. Raman, S.) SWMP. Pub.10. Soil and water management Research unit, G.A.U., Navsari. pp: 111-127.

Patel, K.S., Patel, G.N., Patel, M.K., Pathak, H.C., and Patel, J.K. 2005. Nitrogen requirement of rabi Castor (Ricinus communis L.) under different crop sequences. J. Oilseeds Res., 22 (1) 209210.

Patel, M.K., Fatheh, U.G., and Patel, V.J. 1991. Effect of nitrogen and its time of application on yield of Castor GAUCH1 (Ricinus communis L.) under irrigated condition in north Gujarat. Gau. Res. J., 17(1): 27-29.

Patil, S.J., Mutanal, S.M., Shahapurmath, G.B., and Mannikeri, I.M.2006.Effect of pruning and nutritional levels on growth of Jatropha (Jatropha curcas) under rain fed conditions. Indian $J$. Agroforestry, 8(2): 5-9.

People, T.R., and Koch, D.W. 1997. Role of potassium in carbon dioxide assimilation in Medicago sativa L., Plant physiol., 63: 878-881.

Raghavaiah, C.V. 1999. Performance of Castor (Ricinus communis L.) hybrids under different levels of fertilizer in rain fed conditions on Alfisols. J. Oilseeds Res, 16(2): 295-298.

Raj, A.D., Patel, B.S., and Mehta, R.S. 2010. Effect of irrigation methods on growth, yield and economics of hybrid varieties of Castor (Ricinus communis). The Indian J. Agri. Sci., 80(9): 905-800.

Rajannan, G. 2006. Ecofriendly recycling of primary treated distillery effluent in Jatropha curcas cultivation for greening the wastelands. Report submitted to Director of Research, TNAU, Coimbatore.
Rajgopal, D., Zilberman, D. 2007. Review of environmental, economic and policy aspects of biofuels. World Bank Policy Research Working Paper No. 4341.

Reddy, K.R. and Matcha, S.K. 2010. Quantifying nitrogen effects on castor bean (Ricinus communis L.) development, growth, and photosynthesis. Industrial Crops and Products, 31(1): 185-191.

Reddy, P.K.A., Reddy S.A., and Padmavathi, P. 2006. Effect of irrigation and integrated nutrient management on seed and oil yield of (rabi) castor, Ricinus communis L. J. Oilseeds Res, 23(2): 239-231.

Riyadh, M. 2002. The cultivation of Jatropha curcas in Egypt. Undersecretary of State for Forestation, Ministry of Agriculture and Land Reclamation.

Rodrigues, L.N., Nery, A.R., Fernandes, P.D., Beltrao, N.E. de M. and Gheyi, H.R. 2009. Growth and production of seeds of Castor bean crop irrigated with domestic wastewater. Revista Brasileira de Engenharia Agricola e Ambiental, 13: 825-835.

Samutthong, N., Sarobol, E., Vichukit, V. and Thongpae, S. 2007. Effects of amount and rate of watering on cassava growth and yield potential. Proceedings of the 45th Kasetsart University Annual Conference, Bangkok, Thailand, 30 January-2 February. Subject: Plants, 7582.

Sarhan, A.Z., Daliab, T.M.A., El-Dayem, A.M., and Bahnasy, M.I. 2010. A study of water and fertilization requirements of Jatropha curcas, L. under sewage water irrigation conditions. Bull. Faculty of Agriculture, Cairo University, 61(2):173-181.

Severino, L.S., Ferreira, G.B., Moraes, C.R. de A., Gondim, T. M. de S., Freire, W. S. de A., Castro, D.A., de Cardoso, G. D., and Beltrao, N.E. de 
M.2006.Growth and yield of castor bean fertilized with macronutrients and micronutrients. Pesquisa Agropecuaria Brasileira, 41(4): 563-568.

Sharma, S.K., Gurbachan, S., Rao, G.G., and Yaduvanshi, N.P.S. 2008. Biomass and Biodiesel for Energy Production from Salt-Affected Lands, Technical Bulletin: 2. Central Soil Salinity Research Institute (ICAR). Karnal, India.

Shrisha, A., Reddy, P.K.A., Padmavathi, P., and Madhubindu, G.S. 2010. Evaluation of different integrated nutrient management options on growth and yield of Castor, Ricinus communis L. J. Oilseeds Res., 27(1): 36-38.

Shuman, L.M. 1994. Mineral nutrition In: R.E Wilkinson (ed.) Plant Environment Interactions. New York: Marcel Dekker. pp. 149-182.

Singh, M.S., Rathore, M.S., Chandawat, M.S., and Rao, D.S. 2006. Nutrient management in irrigated Castor, Ricinus communis L. through integrated approach in Rajasthan J. Oilseeds Res., 23(2): 346-347.

Singh, P.K., Singh, B.D., and Rama Kant. 2003. Growth and biomass responses to fertilizer application on mulberry ( Morus alba L.) in sub-tropical conditions. Indian. J. For., 26(1): 9094.

Sree Sesha Saila, P. and Reddy, B.B. 2005. Effect of tillage and soil moisture regimes on seedling emergence, growth and yield of summer Castor, Ricinus communis L. in rice fallows. J. Oilseeds Res, 22(2): 327-330.

Suriharn, B., Sanitchon, J., Songsri, P., and Kesmala, T. 2011. Effects of pruning levels and fertilizer rates on yield of physic nut (Jatropha curcas L.). Asian J. Plant Sci., 10: 52-59.

Swaminathan, C. 2006. Evolving suitable agronomic practices for Jatropha in southern agro-climatic zone. Report submitted to the Director of Research, TNAU, Coimbatore in the year, 2006.

Taiz, L. and Zeiger, E. 2004. Fisiologia vegetal. 3ed. Porto Alegre: Artmed.

Wali, B.M., Palled, Y.B., Kalaghatagi, S.B., Babalal, H.B. and Megeris, S.N. 1991. Response of castor genotype to irrigation and nitrogen. J. Maharastra Agric. Univ., 16: 262-263.

WHO. 2006

http://www.who.int/indoorair/publicatio ns/fuelforlife/en/index.html.

Yadhav, B.B., Khadtar, B. S., Shinde, V.V., and Chavan, S.A. 1995. Performance of different spaced Jatropha curcas as under fertilizer management in Konkan region of Maharashtra. J. Maharashtra Agric. Univ., 20(1): 24-26.

Vergine, Tenshia, J.S. 2006. Effect of fertilizer and manures on growth, yield, nutrient uptake, soil fertility and fuel quality of Jatropha (Jatropha curcas) in vertisols of Coimbatore district. Ph.D thesis submitted to Tamil Nadu Agricultural University, Coimbatore.

\section{How to cite this article:}

Anil Kumar, N.S. Patil, Rakesh Kumar and D. Mandal. 2017. Irrigation Scheduling and Fertilization Improves Production Potential of Jatropha (Jatropha curcas L.): A Review. Int.J.Curr.Microbiol.App.Sci. 6(5): 1703-1716. doi: $\underline{\text { https://doi.org/10.20546/ijcmas.2017.605.185 }}$ 